\title{
KONTRIBUSI TASAWUF-PSIKOTERAPI TERHADAP PENDIDIKAN ISLAM
}

\section{Khairunnas Rajab}

Fakultas Tarbiyah dan Keguruan UIN Suska Riau

Jl. H.R. Soebrantas No.155 KM 18 Simpang Baru Panam,Pekanbaru 28293

E-mail: khairunnasrajab@gmail.com

\begin{abstract}
ABSTRAK
Tulisan ini bermaksud menguraikan sumbangsih psikologi agama yang berkembang menjadi psikoterapi agama dengan corak keislaman (sufistik) terhadap dunia pendidikan khususnya pendidikan Islam. Pendekatan yang digunakan dalam tulisan ini adalah pendekatan filosofis yakni dengan mengkaji bangunan epistemologi tasawuf psikoterapi kemudian dianalisis dalam konteks wacana pendidikan Islam. Pola tasawuf psikoterapi dapat diterapkan dalam pendidikan khususnya pendidikan Islam baik secara substantif, metodis maupun didaktis. Secara substantif pendidikan Islam bertujuan mengajarkan, memperbaiki, membentuk dan menyembuhkan akhlak yang madżûmah menjadi akhlak karimah. Secara metodis, pendidikan Islam bukan hanya sebagai lembaga yang semata-mata mentransfer ilmu kepada murid-muridnya tetapi lebih dari itu ia merupakan lembaga penuntun, pembimbing dan penyembuh bagi murid, orang tua, masyarakat bahkan gurunya itu sendiri. Secara didaktis, guru dan murid bagaikan mursyid dengan muridnya. Guru yang profesional dalam pengertian sufistik adalah guru yang telah menempati maqâmat tertentu seperti zubud, wara', taubah, dan sabar sehingga ia memiliki kematangan dan santun dalam menghadapi muridnya.
\end{abstract}

Kata Kunci: Tasawuf, Psikoterapi, Pendidikan Islam

\section{ABSTRACT}

This paper intends to outline the contribution of psychology of religion psychotherapy that evolved into a religion psychoteraphy with style Islamic (Sufi) on education, especially Islamic education. The approach used in this paper is Philosophical approach that is examining the structure of tasawn psychotherapy that is further analyzed in the context of Islamic education discourse. The pattern of tasawuf psychoteraphy can be implemented in education, specifically in Islamic education, both substantively, methodically, and didactically. Substantively Islamic education aims to teach, improve, form and fix morals of madzmûmah to be karimah moral. Methodically, Islam is not only as an educational institution that solely transfers knowledge to the students, but also as a guide, counselor and healer agency for students, parents, teachers and even society itself. Didactically, the relationship between teacher and student is like mursyid and his students. Professional teacher in Sufi's understanding is the teacher who has occupied a certain maqâmat as zubud, wara', taubah, and patient so that he has the maturity and politeness in facing the students.

Keywords: Tasawuf, Psychotherapy, Islamic Education 


\section{PENDAHULUAN}

Di zaman teknologi informasi dan transformasi ilmu pengetahuan seperti sekarang ini kerap kali terjadi goncangan kebudayaan karena warisan modernisme yakni 'sains yang bebas nilai' masih mengakar dalam kehidupan sehari-hari termasuk di Indonesia. Masyarakat yang terkena dampak langsung warisan budaya modern adalah masyarakat yang hidup dan berdomisili di pinggiran kota-kota besar. Masyarakat ini di satu sisi telah kehilangan citra kedesaannya dan di sisi lain telah terpengaruh gaya hidup perkotaan yang serba mahal dan mewah. Untuk bergaya hidup mewah mereka tidak mampu sedangkan untuk kembali ke gaya pedesaan tidak mau. Akhirnya mereka selalu dalam keadaan depresi berat sehingga mereka terpaksa melakukan pelbagai tindakan krimnal/kejahatan. Hasil survei Ikatan Dokter Indonesia (IDI), melalui Persatuan Dokter Spesialis Kesehatan Jiwa, pada tahun 2007 menyatakan bahwa $94 \%$ masyarakat Indonesia mengalami depresi ringan dan berat (Harian Sijori Mandiri, 2007, halaman muka). Al-Ghalsani menyebutkan bahwa manusia yang berada di persimpangan modern dan postmodern adalah manusia yang menderita secara kejiwaan. Manusia model ini adalah manusia yang banyak murung, gelisah, fobia dan stress. Umumnya mereka mengalami ketidakstabilan emosi, spiritual dan psikologis sehingga ada di antara mereka yang melakukan tindakan bunuh diri. Warisan sains modern yang terlampau materialis, mekanis, fragmentaris dan fragmatis mengabaikan nilai-nilai agama yang normatif serta tidak dipahami secara kritis. Manusia transisional antara modern dan postmodern ini kurang bisa menempatkan antara diri, dunia sekelilingnya, sains dan agama secara seimbang (Al-Ghasani, 1993: 9).

Berkenaan dengan problem manusia modern, Ahmed mengemukakan teori keseimbangan antara agama dengan dunia melalui tasawuf (Ahmed, 1992: 23). Frankl, dengan logoterapinya mengusulkan perbaikan atas dimensi rohaniah manusia agar ia memperoleh kehidupan bermakna. Logoterapi adalah pemberdayaan nilai rohani (kejiwaan) dalam mengobati pasien yang menghadapi kemurungan, ketegangan, kecemasan dan kerisauan. Badri menilai bahwa Frankl telah menggunakan pendekatan psikologi optimistik yang bukan hanya selaras dengan prinsip-prinsip humanisme tetapi juga dengan agama dalam mencapai makna hidup (Badri, 1979: 74). Manusia bukan hanya makhluk yang berdimensi fisik semata melainkan juga berdimensi ruhaniah atau kejiwaan. Manusia adalah makhluk yang berdimensi fisis dan psikologis. Keduanya saling membutuhkan dan saling mengisi serta saling bersinergi. Oleh karena itu manusia selalu dianggap sebagai makhluk yang paling rumit dan penuh teka-teki, abstrak dan misterius. Dalam rangka memahami manusia, telah lahir pelbagai ilmu tentang kemanusiaan diantaranya adalah psikologi.

Pendiri psikologi, Wundt (1883-1920) mengajukan metode dasar psikologi sebagai pengamatan eksperimental ke atas diri seseorang yang disebut dengan metode introspeksi (Wundt, 1973). Wundt meyakini bahwa tugas utama psikolog adalah menyelidiki serta mempelajari proses dasar kesadaran manusia 
sebagai pengalaman langsung, kombinasi dan hubungannya, laiknya ahli kimia saat meneliti elemen dasar suatu zat. Bagi Wundt yang terpenting adalah mempelajari cara kerja mental yang terpusat kepada perhatian, maksud serta tujuan yang dimiliki seseorang. Wundt mengembangan satu metode yang disebut sebagai analytic introspection (intropeksi analitik), yaitu satu bentuk formal dari observasi yang dilakukan terhadap diri sendiri (Davidoff, 1988: 11-12). Individu selalu mencari jawaban atas diri, kehidupan di dunia, ketenangan dan kebahagiaan serta kehidupan setelah kematian. Hazrat Pir menguraikan, bahwa ada dua pertanyaan mendasar berkenaan dengan perilaku manusia. Pertama, bagaimana manusia sempurna (insan kamil) dapat dibentuk? Kedua, bagaimana masyarakat sempurna dapat dibina? (Nader Syah, 1987: 97).

Iqbal menyebut Muhammad SAW sebagai satu-satunya manusia yang dapat menjadi insan kamil. Muhammad SAW dipandang Iqbal sebagai seorang yang ma'shûm, yang terbebas dari dosa dan maksiat. Muhammad adalah seorang Nabi yang memiliki kepribadian rabbani yang secara holistik bisa menyesuaikan diri dengan alam, lingkungan, umat Muslim ataupun non Muslim (Rahmat, 1991). Secara umum Muhammad SAW telah menguraikan bagaimana mewujudkan kebahagiaan dan kesehatann mental. Pertama, menguatkan aspek rohani. Selama 13 tahun Muhammad SAW menghabiskan waktunya untuk meluruskan akidah dengan meneguhkan akar-akar keimanan ke dalam hati umat dan membersihkannya dengan mempraktikkan ibadah-ibadah dan ber-taqarrub kepada Allah. Iman yang tertanam dalam hati umat telah mengubah kepribadian bangsa Arab dari belenggu jahiliyyah menjadi bangsa yang berkebudayaan tinggi. Kedua, dengan mengendalikan kesadaran manusia agar senantiasa eksis dalam perlindungan al-Qur'an. Muhammad mengajarkan umatnya untuk memenuhi kebutuhan ini dengan jalan halal dan tidak mubadzir (Najati, 1993: 8-10).

Sebaliknya, manusia modern-postmodern cenderung kurang memiliki raushan fiker (pemikir tercerahkan). Raushan fiker yaitu orang yang mengenal Allah, memahami dunia dan menemukan nilai-nilai luhur yang dikaruniakan Allah SW'T kepadanya. Manusia transisional adalah manusia yang secara umum pesimis sehingga selalu dalam keadaan bimbang serba salah paham dalam mendidik diri secara layak. Dalam konteks mendidik diri, Syariati menafsirkan al-Qur'an Surat al-Rum [30]: 60 yang menyatakan; "Karena itu bersabarlah engkau hai Mubammad, sesungguhnya janji Allah adalah benar dan janganlah engkau merasa berkecil hati terhadap orang-orang yang tidak meyakini hari kiamat itu”. Menurut Syariati, ayat ini sangat pas dalam mendasari manusia transisional yang butuh cara untuk mendidik diri dengan raushan fiker (Syariati, 1995: 131). Dalam konteks yang lebih formal, mendidik diri mestinya menjadi tujuan inti pendidikan terutama pendidikan Islam.

Tulisan ini bermaksud menguraikan sumbangsih psikologi agama yang berkembang menjadi psikoterapi agama dengan corak keislaman (sufistik) terhadap dunia pendidikan khususnya pendidikan Islam. Pendekatan yang digunakan dalam tulisan ini adalah pendekatan filosofis yakni dengan mengkaji 
bangunan epistemologi tasawuf psikoterapi kemudian dianalisis dalam konteks wacana pendidikan Islam.

\section{PEMBAHASAN}

\section{Psikterapi Agama}

Nilai agama akhir-akhir ini menjadi isu yang banyak dibicarakan dalam bidang psikologi. Hal ini terjadi karena pertama, sains telah kehilangan otoritasnya sebagai sumber kebenaran. Ini tercermin dalam sejumlah analisis yang berhasil menunjukkan bahwa ilmu sebenarnya merupakan suatu bentuk budaya intuitif (kata hati) dan mengandung nilai (Polanyi, 1962: 162). Oleh karena itu, dimensidimensi ekologi sosial dan politik dari kemajuan sains dan teknologi memberikan pengaruh yang sangat besar terhadap perkembangan kejiwaan individu. Pada era postmodern, tidak mesti semua karya teknologi divonis dengan begitu saja sebagai satu tanda kemajuan. Meskipun kepercayaan terhadap keakuratan metode ilmiah masih bertahan, akan tetapi muncul kekecewaan sehubungan dengan cara-cara pemanfaatan ilmu sebagai produk dari metode tersebut. Muncul kepercayaan baru dari masyarakat terhadap sains bahwa sebagai problem solver bagi masalah-masalah kemanusiaan, sains sudah mulai diragukan (Bergin, 1994: 4). Kedua, Psikologi yang pada masa modern telah dianggap sebagai salah satu disiplin ilmu yang dapat memberikan otoritas bagi perilaku manusia, kini telah kehilangan pamornya saat dihadapkan terutama dengan perilaku manusia yang didasarkan pada nilai-nilai keagamaan. Pada masa modern, psikologi behavioristik telah mencapai kejayaannya tetapi kini ia dikritik dan dikecam oleh para profesional/psikolog praktis/psikoterapi yang tidak berdaya ketika berhadapan dengan kasus-kasus yang berhubungan dengan keagamaa (Frankl, 1970: 35). Ketiga, era modern telah menimbulkan kecemasan, keterasingan, kekerasan, egoisme, kemurungan, ketegangan, psikosis, dan neurosis yang mengakibatkan ketidakstabilan emosi. Hal ini terjadi karena unsur keagamaan telah dipinggirkan. Akibatnya, persentase penderita penyakit mental dan gangguan mental meningkat (al-Ghalsyani, 1992: 9). Keempat, semangat kemanusiaan yang muncul di kalangan psikolog telah menunjukkan tanda-tanda positif dan berpeluang untuk mewujudkan dimensi psikologis manusia ke arah yang lebih baik dengan menawarkan pengalaman-pengalaman spiritual sebagai salah satu metode yang dapat digunakan untuk mengatasi masalah-masalah kemanusiaan. Para psikolog yang terlibat dalam gerakan ini adalah Victor E. Frankl, William James, Carl Jung, Gordon W. Allport, serta berdirinya organisasi besar seperti, American Psycholocical Associations's Division, Society for the Scientific Study of Religion, dan American Catholic Psychological Association. Menurut mereka, pengalaman-pengalaman spiritual dapat berkontribusi terhadap kesehatan mental seseorang. Ketika pengalaman spiritual tersebut tidak diperhatikan maka kesehatan yang diidamkan para psikolog hanya merupakan utopia (Malony, 1997: 129). 
Ada dua metode yang berhubungan langsung dengan psikologi, yaitu research methods (metode penelitian) dan psychoterapy methods (metode psikoterapi). Research methods lebih menitikberatkan kepada eksperimen-eksperimen yang dilakukan secara objektif. Penelitian lebih banyak dilakukan dalam laboratorium. Pendekatan eksperimen ini, mensyaratkan metode pengukuran (reliability dan validity) sebagaimana lazimnya penilain kuantitatif. Psikoterapi lebih menitikberatkan kepada soal pengkajian metode perawatan dan pengobatan individu, keluarga, dan komunitas masyarakat, yaitu sebuah penilaian kuantitatif (Wilcox, 2003: 50).

Psikologi yang berbasis pada metode penelitian (research methods) merupakan suatu disiplin ilmu yang menyelidiki perilaku individu manusia secara dekriptif. Dari upaya tersebut muncul teori-teori psikologi. Teori-teori ini kemudian berkembang menjadi disiplin ilmu tersendiri diantaranya yaitu psikoterapi. Psikoterapi menawarkan sebuah teori, teknik dan metode yang digunakan dalam rangka melakukan proses pemulihan, perawatan dan pengobatan pasien-pasien psikosis. Psikoterapi adalah cabang psikologi dalam suatu proses perawatan individu yang mengalami gangguan mental, kemurungan, tekanan, stres, depresi, neurosis, psikosis, fobia, atau penyakit mental lainnya seperti individu yang sedang menghadapi masalah mental sebagai dampak dari penggunaan narkoba. Stres, depresi, kemurungan, neurosis dan psikosis pada hakikatnya adalah pengaruh dari adanya ketidakseimbangan antara IQ (inteligent quotient), EQ (emotional quotient), dan SQ (spiritual quotient). Seorang individu yang selalu mengutamakan IQ biasanya menganggap remeh dimensi sosial di mana ia hidup. Individu yang menggunakan EQ cenderung memperhatikan nilai-nilai masyarakat tetapi kurang memperhatikan persoalan moral yang ada di sekitarnya. Dengan demikian, pengunaan baik IQ maupun EQ secara sepihak belum menunjukkan sebagai manusia sempurna. Untuk mencapai kesempurnaannya, seorang individu memerlukan kecerdasan lain yaitu SQ. Ia dapat menjadikan seseorang, dalam proses berfikirnya, senantiasa memperhatikan hubungan antara daya fikir dengan emosi dalam terang bimbingan spiritual yang baik. Itulah sebabnya, dalam analisis Taufiq Pasiak, penyebab ketidaksehatan mental seperti adanya tekanan, depresi, psikosis, psikoneorosis dan kemurungan terjadi karena adanya mismanagement dalam fikiran. Selisih antara apa yang dimiliki dan apa yang dicapai (das sein) dengan apa yang diinginkan dan apa yang diharapkan (das solen) mendorong lahirnya penyakit mental/ketidaksehatan mental (Pasiak, 2004: 50).

Problem di atas mendasari psikoterapi berbasis keagamaan. Psikoterapi yang berbasis wawasan keagamaan menjadikan nilai-nilai moral, norma, dan agama, sebagai pemandu dan petunjuk dalam rangka menyembuhkan pasien. Dalam psikoterapi berbasis keagamaan, aspek spiritual merupakan aspek penting yang mampu memberi kesegaran rohani yang berarti dalam menumbuhkembangkan kesehatan mental (Agustian, 2004: 142). Psikoterapi dalam bentuk ini, memberikan gambaran yang jelas bahwa perlu sebuah 
pendekatan baru yaitu pendekatan spiritual yang dapat digunakan dalam rangka merawat/ menyembuhkan individu dari gangguan mental.

\section{Tasawuf Psikoterapi}

Islam merupakan agama yang mengajarkan nilai-nilai spiritual sehingga diyakini mampu menyelesaikan masalah-masalah psikologis manusia. Dimensi Islam seperti iman, ibadah, mu'amalah, akhlak, dan tasawuf memiliki metodologi tertentu yang secara sistematik dapat membantu manusia mewujudkan kesehatan mental. Secara keilmuan, psikoterapi ini berbasis ilmu tasawuf dan secara normatif implementasinya didasarkan pada nilai-nilai yang terdapat dalam alQur'an dan Sunnah Nabi Muhammad SAW. Kualitas iman, ibadah, muamalah, akhlak dan terutama manhaj tasawuf yang sudah teruji akan dijadikan metode pembentukan manusia yang sehat secara mental. Kesehatan mental ini tercermin dalam ketenangan, ketenteraman dan keselarasan kehidupan baik antara diri, orang lain dan alam.

Islam adalah agama yang diturunkan kepada Muhammad SAW yang berupaya membangun umat manusia dalam mencapai kesejahteraan, kedamaian dan kebahagiaan hidup (Nasution, 1997: 23). Islam memotivasi penganutnya untuk selalu dekat dengan Tuhan/Allah SW'T dan senantiasa menciptakan hubungan yang baik di antara sesama manusia (hablun min al-nâs) serta tidak mengganggu dan menganiaya hewan, tumbuh-tumbuhan dan alam semesta (Madjid, 1992: 102). Kualitas manusia semacam ini disebut dengan muttaqin yakni orang yang selalu berupaya menciptakan kemaslahatan umat manusia, memberi solusi atas persoalan-persoalan hidup dan berambisi membentuk komunitas yang damai dan penuh persaudaraan (Najati, 2001: 235).

Ritual-spiritual melalui tasawuf secara metodologis berdimensi preventive (pencegahan), curative (pengobatan), constructive, dan rehabilitative (pembinaan) (Jaya, 1992: 15). Ketika dimensi metodologis tersebut dikombinasikan dengan perilaku keberagamaan lain seperti jihad maka dapat melahirkan suatu motivasiinovatif yang dapat membentuk terapi keislaman (klinikal Islam) (Rahmat, 1999: 37). Jihad dalam konteks bertasawuf menjadi serangkaian langkah-langkah tazkiyyah an-nafs (pembersihan dan penyucian jiwa) hati dan jiwa manusia yang telah dikotori dengan kekotoran duniawi.

Dalam konteks tasawuf, iman pun secara aplikatif dapat melahirkan arketif kesadaran, bahwa manusia selalu diawasi Allah SWT sehingga ia selalu berlaku jujur (Nurbakh, 1991: 13). Secara psikologis orang yang mukmin/beriman mampu menekan hawa nafsunya untuk tidak berlaku negatif dan merusak. Ibadah dalam konteks sufistik juga berpengaruh positif terhadap kejiwaan seorang. Ia sebagai 'âbid (hamba Allah) senantiasa beramal dengan penuh keikhlasan, kesungguhan, berkhidmat, bertawadhu', dan khusu' yang berdampak pada perilaku sehari-hari secara lebih baik (Ma'luf, 1986: 483). Akhlak dan tasawuf merupakan iman yang termanifestasikan dalam kepribadian umat Islam yang patuh dan taat kepada aturan dan konsekuen dalam bertindak. Muatan- 
muatan yang dimiliki akhlak-tasawuf dapat dijadikan sebagai langkah-langkah terapeutik (pengobatan) untuk menghasilkan kesehatan mental yang paripurna. Akhlak dan tasawuf juga mampu menyelaraskan hubungan antara Allah, manusia dan alam secara ekologis (Miskawaih, 1961: 19).

Al-Qur'an menyifati manusia sebagai makhluk yang paling sempurna dan sebaik-baik bentuk (Q.S. Al-Tin [95]: 4) serta makhluk yang mulia dibandingkan dengan makhluk lainnya (Q.S.Al-Isra' [17]: 70). Manusia juga diberi sejumlah potensi yang baik maupun yang buruk (Q.S. Al-Syams [91]: 8). Dalam proses menuju kesempurnaannya itu, manusia merupakan subjek yang sadar dan bebas menentukan pilihan; baik atau buruk, bajik atau jahat, taqwa atau fujr dan jalan yang menyebabkan dirinya terpelihara atau binasa. Di bagian lain al-Qur'an menyifati manusia sebagai makhluk yang dalam setiap perbuatan dan kehidupannya dilingkupi dengan ketergesa-gesaan (Q.S.Al-Isra' [17]: 11). Jika tidak hati-hati, manusia pun dapat menzalimi dirinya dan orang lain serta ingkar kepada aturan Tuhannya (Q.S. Ibrahim [14]: 4). Dalam menjalani kehidupannya pun manusia cenderung berkeluh kesah (Q.S. Al-Ma'arij [70]: 19). Manusia dengan mudah dapat bertengkar dengan sesamanya (Q.S.. Al-Kahfi [18]: 54). Padahal di ayat lain, manusia itu adalah makhluk yang sangat dha'îf. (Q.S. AlNisa' [4]: 28).

Tujuan utama tasawuf-psikoterapi adalah menciptakan kesehatan mental manusia. Kesehatan mental dalam Islam merupakan kekuatan emosionalpsikologis yang menempatkan manusia sebagai subjek pengamal agama mulai dari dimensi ritual (ibadah), credoism (iman) hingga ke norma (akhlak) yang berlaku dalam suatu masyarakat. Sehat secara mental tidak terlepas dari pembentukan akhlak. Akhlak yang baik tercermin dalam tindakan toleran, pemaaf, sadar untuk tidak mengganggu ketenangan orang lain dan menjalin hubungan baik dengan Tuhannya (al-Ghazali, 1994: 29-31). Jika esensi dari proses perkembangan jiwa manusia itu berhubungan dengan pertumbuhan, pembinaan, dan pengembangan nilai al-akhlâq al-karimah (moral yang baik) maka akhlak adalah kualitas-kualitas moral yang secara khusus melekat kepada manusia dan terwujud secara nyata dalam keadaan ahsan al-taqwîm (sebaik-baik bentuk dan rupa). Tanpa akhlak, manusia akan kehilangan esensi dan identitas dirinya lalu menjadi asfala sâfilin (makhluk yang tidak bermoral) (Effendi, 1991:5). Tasawufpsikoterapi itu bertujuan memelihara, menyembuhkan dan mengembangkan hati, ruh, nafsu dan akal agar selalu berada dalam keadaan salâm atau Islâm. Kondisi ini tergambar dalam firman Allah SWT yaitu "Sesunggubnya bukanlah mata itu yang buta, tetapi yang buta itu adalah hati yang ada dalam dada" (Q.S. Al-Hajj [22]: 46). Semua manusia mempunyai hati tetapi tidak semua manusia mampu dan menggunakannya untuk memahami, menghayati dan mengamalkan perintah Tuhan (Q.S. Al-A'raf [7]: 176). Manusia justru lebih banyak menuruti bisikan setan sehingga di dalam hati manusia yang demikian itu ada penyakit dan lambat laun hatinya pun menjadi kasar (Q.S. Hajj [22]: 53). Dalam hati manusia yang penuh dengan bisikan setan selalu ada penyakit lalu ditambahkan oleh Allah 
penyakitnya (Q.S.Al-Baqarah [2]: 10). Sekali-kali tidak! Bahkan apa yang mereka kerjakan itu telah menutupi hati mereka (Q.S Al-Mutaffifin [83]: 14). Allah telah mengunci hati dan pendengaran mereka, bahkan penglihatan mereka ditutup dan mereka akan mendapat azab yang berat (Q.S. Al-Baqarah [2]: 7). Hati kecil orang-orang yang tidak beriman kepada hari akhirat cenderung tertarik kepada bisikan setan dan menyenanginya sehingga mereka melakukan apa yang biasa mereka lakukan (Q.S. Al-An'am [6]: 113). Pada saatnya nanti, yaitu pada hari di mana harta dan anak-anak tidak lagi berguna mereka baru menyadarinya, ternyata hanya orang-orang yang hatinya bersih yang mampu menghadap Allah SWT (Q.S. Al-Syu'ara' [26]: 88 dan 89). orang tersebut adalah orang yang telah diuji hatinya oleh Allah untuk senantiasa bertaqwa (Q.S.Al-Anfal [8]: 24). Barang siapa yang beriman kepada Allah, maka Dia akan memberi petunjuk kepada hatinya (Q.S.Al-Taghabun [64]: 11).

Konsep hati dengan pelbagai penerapannya di atas memberikan pengertian bahwa hati yang tulus (ikhlas) yang menentukan hakikat diri manusia itu adalah hati yang dapat memahami, mengetahui apa yang melekat padanya dan lingkungan dirinya. Untuk mencapai hati yang bersih dan ikhlas itu memerlukan bimbingan syariat. Secara spiritual, tahapan itu bisa terwujud dengan memperbanyak zikir kepada-Nya dengan tekun dan secara terusmenerus. Dengan berzikir akan tercipta dan terbangun kesehatan hati (mental) yang lebih baik (Hawwa, 1998: 61). Hati yang terbebas dari penyakit seperti hasad, riya, pengumpat, sombong dan menggunjing akan membuka bijab ke arah moral/akhlak yang mulia.

Meskipun Islam telah menegaskan bahwa hakikat roh bukan urusan manusia dan jika manusia bersikukuh ingin mengetahuinya maka manusia hanya dapat mengetahuinya sedikit saja (Q.S. Al-Isra' [17]: 85). Namun di awal penciptaan manusia, roh telah diperkenalkan Tuhan kepada manusia, Allah menjelaskannya dalam firman-Nya yang artinya: "Dan ingatlab ketika Tubanmu mengeluarkan dari sulbi (tulang belakang) anak-cucu Adam keturunan mereka dan Allah mengambil kesaksian terbadap roh mereka (seraya berfirman): Bukankah aku ini Tubanmu? Mereka menjawab "betul" engkau Tuban kami" (Q.S. Al-A'raf [7]: 172).

Namun roh dipengaruhi oleh sejumlah faktor eksternal/lingkungan diantaranya adalah faktor keluarga. Keluarga cukup dominan dalam membentuk aspek ruhaniah seseorang. Faktor moral sosial yang bebas nilai tanpa disertai nilai keimanan dapat membentuk ruhaniah seseorang cenderung kepada kemungkaran, kesombongan dan kemaksiatan. Kedua faktor ini jika tidak dididik dengan tepat dapat mendesak roh bertindak spekulatif dan melakukan pelanggaran sosial (social deviation). Eksistensi roh agar tetap berada dalam latiffah rûbâniyyah rabbâniyyah (roh halus ketuhanan) memerlukan pendidikan yang seimbang dan selaras dengan ubûdiyyah (amalan). Sebetulnya, roh itu telah mengenal Tuhannya sejak awal penciptaannya, yakni ketika bersaksi bahwa Allah 
sebagai Tuhannya, maka ketika seseorang berperilaku jauh dari kerohaniahannya seseungguhnya ia telah menghianati perjanjian antara dirinya dengan Tuhannya.

Nafsu yang terdapat dalam diri manusia dapat menjadi energi positif dan negatif. Konsep nafsu dalam al-Qur'an bermakna diantaranya sebagai nafs alammârah yaitu nafsu yang mempunyai segala macam bentuk agresivitas dan tindakan destruktif manusia; nafs al-lawwâmab; dan nafs al-mutma'innah (Rahman, 1995: 21). Nafs al-ammârah cenderung memerintah manusia melakukan tindak kejahatan (bil al-su') yang tunduk dan taat kepada kemauan dan godaan syaithan. Allah berfirman: 'Dan aku tidak (menyatakan) diriku bebas (dari kesalahan), karena sesunggubnya nafsu itu selalu mendorong kepada kejahatan, kecuali (nafsu) yang diberi rabmat oleb Tuban-ku, sesunggubnya Tuban-ku Maha Pengampun, Maha Penyayang." (Q.S. Yusuf [12]: 53). Nafs al-lawwâmah juga cenderung mendorong seseorang melakukan tindak kejahatan tetapi di dalamnya ada rasa sesal dan segera kembali kepada Tuhannya untuk bertaubat. Nafsu ini dapat pula mencerca pemiliknya ketika dia lalai dalam melakukan pengabdian kepada Tuhannya. Allah berfirman: "Dan aku bersumpah dengan jiwa yang selalu menyesali (dirinya sendiri)." (Q.S. AlQiyamah [75]: 2). Apabila nafsu tunduk dan patuh kepada Tuhan-Nya dan merasa resah dan takut karena meninggalkan perintah-Nya, maka nafsu ini disebut nafs al-mutma'innah (jiwa yang tenang) (Hawwa, 1998: 46). Allah menyatakan dalam al-Qur'an: "Hai jiwa yang tenang, kembalilah kepada Tubanmu dengan hati yang ridha lagi diridhai-Nya." (Q.S. Al-Fajr [89]: 27 dan 28). Akal berperan penting dalam kehidupan manusia dan karena akal pula semua perbuatan manusia harus dapat dipertanggungjawabkan di hadapan Tuhannya. Akal sebagaimana roh dan nafsu juga memiliki kecenderungan baik dan buruk. Akal yang diberi taklifi menjadikan akal berbuat sesuai kodratnya, yaitu bajik dan bijak.

Dalam tasawuf, empat dimensi psikologis manusia; hati, roh, nafsu, dan akal memiliki potensi pembinaan dan pengembangan mental dan moral menuju akblâq karimah yang sesuai dengan fitrahnya yang suci, putih, bening, dan bersih yang dibawanya semenjak lahir. Nabi SAW bersabda: "Tidak seorang juapun anak yang baru labir, melainkan dia dalam keadaan suci bersih. Kedua orang tuanyalah yang menyebabkan dia menjadi Yahudi, Nasrani atau Majusi ". Allah berfirman: "Maka hadapkanlah wajahmu dengan lurus kepada agama (Islam); (sesuai) Fitrah Allah karena Dia telah menciptakan manusia menurut fitrahnya itu; tidak ada perubahan pada ciptaan Allah. Itulah agama yang lurus, tetapi kebanyakan manusia tidak mengetabuinya." (alQusyairy, 1914: 242).

Islam memandang manusia, sebagai makhluk unik yang memerlukan pembinaan dan pengembangan supaya menjadi insan yang mengenal dirinya dan selalu mendekatkan diri kepada Tuhannya. Dengan cara itu manusia dapat mencapai tahapan spiritual yang tinggi serta meraih kesempurnaan dan kesucian rohaniah yang murni. Aktivitas yang demikian disebut oleh para sufi sebagai tazkiyyat an-nafs yaitu suatu proses perkembangan psikologis manusia menuju kondisi batiniah yang al-falâh (menang), al-najâh (sukses) dan mutma'innah 
(tenang). Kemenangan, kesuksesan, ketenangan, kebahagiaan (bappiness/alsa âdah) sebenarnya adalah kumpulan ketenangan mental dalam satu kesatuan pribadi yang utuh (Darajat, 1988: 13). Ketenangan mental (mutma'innab) dapat diraih dengan mengingat Allah dan beramal shaleh (Q.S. Al-Ra'd 13: 29). Ketenangan jiwa dapat diraih dengan menghilangkan gangguan-gangguan yang dapat menghambat proses tadzkiyyah al-nafs. Gangguan itu biasanya lahir dari sikap (attitude) rasa berdosa, bersalah dan perasaan dendam (Darajat, 1989: 18). Keadaan psikologis orang yang berbuat dosa dan maksiat selalu dihantui rasa gelisah dan cemas selama rasa berdosa itu melekat dalam dirinya (Jaya, 1992: 58).

\section{Kontribusi Tasawuf Psikoterapi Terhadap Pendidikan Islam}

Di dalam ilmu pendidikan terdapat aspek kurikulum, guru, metode, sarana dan prasarana, lingkungan, bimbingan, proses belajar-mengajar, pembiayaan dan pengelolaan serta penilaiannya. Semua aspek pendidikan tersebut pada dasarnya ditujukan dalam rangka memenuhi tujuan pendidikan. Dalam konteks pendidikan Islam, tujuan pendidikan itu selalu berhubungan dengan upaya membangunan manusia yang berakhlak mulia. Marimba bahkan menegaskan bahwa tujuan pendidikan Islam itu identik dengan tujuan hidup seorang muslim yaitu menjadi hamba Allah SWT yang berarti percaya dan berserah diri kepadaNya (Marimba, 1980: 48-49). Pengertian tersebut memperkuat pendapat alAbrasyi yang mengatakan bahwa pendidikan budi pekerti merupakan jiwa dari pendidikan Islam karena memang Islam telah menegaskan bahwa mencapai akhlak yang sempurna merupakan tujuan yang sebenarnya dari pendidikan (alAbrasyi, 1974: 15). Al-Attas pun menambahkan bahwa tujuan pendidikan Islam adalah memanusiakan manusia secara baik dan benar (al-Attas, 1984: 1). Abdul Fatah Jalal mengatakan bahwa tujuan umum pendidikan Islam itu mewujudkan manusia sebagai hamba Allah yang sesungguhnya yakni seorang hamba Allah yang tunduk, taat dan patuh dalam melaksanakan segala perintah-Nya dan menjauhi segala larangan-Nya serta tentu saja memiliki sifat-sifat dan akhlak yang mulia (Jalal, 1990: 119).

Berdasarkan penjelasan di atas dapat diperoleh suatu pemahaman bahwa kesehatan mental/jiwa yang termanifestasikan dalam tingkah laku kehidupan sehari-hari yang berakhlak mulia merupakan inti sari dari pendidikan Islam. Dalam arti yang lain pendidikan Islam merupakan sarana kelembagaan Islam yang dapat digunakan oleh tasawuf psikoterapi dalam membentuk peserta didik bahkan semua orang yang terlibat di dalamnya termasuk guru dan staf administrasi gar memiliki jiwa/mental yang sehat. Dengan demikian seluruh aspek pendidikan Islam lainnya seperti kurikulum, keuangan, materi pelajaran, metode dan teknik evaluasi harus sehat secara mental dan spiritual.

Dalam aspek peserta didik sebagai insan manusia memiliki tiga matra yaitu badan, akal dan ruh. Kesempurnaan kepribadian seseorang bergantung pada keharmonisan tiga matra tersebut. Ketika terdapat kepincangan di antara salah satunya maka timbul ketidakserasian yang dapat mengancam keutuhan pribadi 
peserta didik. Sebagai generasi penerus suatu bangsa maka tidak menutup kemungkinan di masa depan perilaku mereka berdampak pada tatanan masyarakat yang juga disharmoni. Dalam hubungannya dengan persoalan generasi, Rasulullah saw bersabda "tenangkanlah hati dari masa ke masa" (alSyaibani, 1979: 131-132).

Kurikulum pendidikan Islam yang berlandaskan pada akhlak tasawuf dan psikoterapi senantiasa menempatkan dimensi akhlak sebagai isinya dan treatment/tindakan/perlakuan sebagai metodenya. Isi kurikulum adalah segala hal yang didasarkan pada al-Qur'an, Sunnah dan peninggalan orang-orang terdahulu yang shaleh. Secara metodis, kurikulum model ini menekankan pada pembimbingan terhadap segala aspek pribadi pelajar terutama aspek psikologis dan spiritual yang berlandaskan kepada akidah dan sifat-sifat ketuhanan/keilahian seperti menjadi pemaaf, welas asib terhadap sesama namun tegas dalam menghadapi kemunkaran, kemunafikan dan penyakit hati lainnya (alSyaibani, 1979: 490-491).

Dalam aspek metode mengajar, dalam konteks tasawuf psikoterapi, yang dipentingkan adalah proses. Proses pembelajaran merupakan proses penghubung antara pelajar dengan pengajar dalam mengubah tingkah lakunya. Di sini ada pengandaian bahwa kematangan sang pengajar merupakan hal yang niscaya. Ketika sang pengajar telah matang terutama secara spiritual maka ia akan berperan sebagai pembimbing dan pemberi petunjuk kepada pelajar. Dalam konteks tasawuf sang pengajar adalah mursyid dan si pembelajar adalah murid. 'Adâb al-mu'alimin adalah sopan santun guru dalam mengajar. Sopan santun atau adab membuka pintu faedah atas ilmu yang diajarkan oleh guru dan dipelajari oleh murid. Tanpa adab sekolah akan menjadi biadab (al-Syaibani, 1979: 555556). Dengan demikian guru harus memiliki kedudukan dan perilaku yang jauh lebih mulia dibanding dengan murid-muridnya. Agar mampu memberikan bimbingan bahkan mengobati murid, guru harus mencapai maqâmat/stages/tempat/pangkal/tangga tertentu yang mulia dengan ciri memiliki tingkat kedekatan tertentu dengan Allah SWT. Beberapa maqâmat tertentu diantaranya adalah sebagai berikut:

1. Zubud, artinya cenderung menghindari hal-hal yang bersifat duniawi/materi/kesenangan/kehidupan yang serba gemerlap oleh harta, kedudukan dan jabatan (Nata, 2012: 194-195). Dalam konteks zubud ini guru yang berwawasan sufistik ketika mengajar bukan sematamata demi gaji atau tunjangan. Guru profesional dalam arti sufistik adalah guru yang ikhlas mengajar muridnya dengan tujuan utama membentuk dan mencetak murid menjadi insan yang saleh, berilmu dan bermanfaat bagi orang lain. Guru yang zubud bukan berarti ia menolak untuk digaji tetapi gaji yang dia peroleh lebih banyak digunakan untuk meningkatkan kemampuan dan kompetensinya dengan cara menuntut ilmu ke jenjang yang lebih tinggi, membantu murid yang yatim dan kekurangan dalam biaya padahal murid tersebut 
memiliki potensi yang baik untuk menjadi cerdas dan saleh. Guru yang bersikap zuhud adalah guru yang telah meyakini hikmah karena itu ia menjauhi sikap bermewah-mewahan dan orang yang berhikmah adalah orang yang sebaik-baiknya mengajar. Allah berfirman: "Serulah (manusia) kepada jalan Tubanmu dengan hikmah dan pelajaran yang baik dan bantablah mereka dengan cara yang baik. Sesunggubnya Tubanmu Dialah yang lebih mengetabui tentang siapa yang tersesat dari jalan-Nya dan Dialah yang lebih mengetahui orang-orang yang mendapat petunjuk." (Q.S. An Nahl [16]: 125). Atas dasar ayat tersebut Rasulullah SAW bersabda: "Jika kamu melihat seseorang yang telah dianugerabi sifat zubud dalam dirinya dan selalu lurus sikapnya, maka dekatilah orang itu, karena orang itu telah meyakini hikmah." (al-Qusyairiyah, tt: 115 dalam Nata, 2012: 196).

2. Al-Taubah, artinya kembali dan senantiasa memohon ampun atas segala dosa dan kesalahan disertai janji yang sungguh-sungguh tidak akan mengulangi perbuatan dosa tersebut serta disertai dengan melakukan amal kebajikan. Dalam konteks sufistik orang yang bertobat adalah orang yang selalu berlatih (riyâdab) dan berjuang (mujâhadah) dalam usaha membuka tabir (bijâb) yang membatasi antara dirinya dengan Tuhan (Zahri, 1995: 105-106). Pendidikan dalam arti ini hendaknya berupaya membentuk murid yang selalu menghindari perbuatanperbuatan yang keji dan berdosa seperti menyontek saat ujian berlangsung. Dalam pandangan sufistik, menyontek pada saat ujian sama saja dengan menantang Tuhan sebab siswa yang menyontek seolah menganggap bahwa Tuhan tidak ada/tidak melihat perbuatannya itu. Dalam sufistik, siswa yang menyontek adalah siswa yang melakukan kebohongan berlipat-lipat. Ia telah membohongi diri sendiri, guru, orang tua, negara dan Tuhan karena nilai yang tertera dalam ijazah adalah nilai hasil kebohongan. Orang yang berbohong bagaimanapun juga termasuk ke dalam orang yang tidak sehat secara mental sebab ia senantiasa mengingkari kenyataan hidup.

3. Al-Wara', artinya saleh dan menjauhi hal-hal yang tidak baik, meninggalkan segala hal yang di dalamnya terdapat keraguran antara halal dan haram (syubhat). Sikap ini sejalan dengan hadis Nabi SAW; Barang siapa yang dirinya terbebas dari syubhat maka sesungguhnya ia telah terbebas dari yang haram (HR.Bukhari dalam Nata, 2012: 199). Saat ini menghindari dari yang syubhat sangat sulit, misalnya dalam hubungannya dengan pemenuhan kebutuhan minuman dan makanan. Jenis minuman dan makanan itu sendiri menentukan kualitas halal atau haram, akan tetapi yang paling sulit adalah menentukan kualitas cara makanan itu diperoleh. Boleh jadi makanan yang kita beli itu secara kasat mata halal karena kita beli dari uang yang kita peroleh dari hasil bekerja. Akan tetapi orang sering lupa proses dan cara seseorang pertama kali memperoleh kerja tersebut, misalnya dulu ia diterima 
bekerja di kantor/perusahaan tersebut karena melalui nepotisme bahkan suap. Dalam pandangan sufistik setiap pembelian barang yang diperoleh dari uang penghasilan dari tempat bekerja tersebut dikategorikan penghasilan yang syubhat bahkan mungkin haram. Oleh karena itu baik guru maupun murid penting memperhatikan perilaku wara' ini dalam menghadapi godaan zaman yang semakin terjebak pada kesenangan materi, keriuhan dalam meraih jabatan dan kekuasaan serta keengganan mengikuti pola hidup sederhana. Akibatnya, berbagai penyakit baik itu fisik maupun non fisik mudah menyerang setiap manusia yang berperilaku hedonis. Rata-rata orang yang berperilaku hura-hura, bermewah-mewah dan menghamburkan harta kekayaannya adalah orang-orang yang tidak bisa bersyukur atas nikmat yang diraihnya.

4. Shabar, artinya 'tabah hati' dan 'tetap hati' (Yunus, 1972: 211). AlMishry mengartikan bahwa sabar itu menjauhkan diri dari hal-hal yang bertentangan dengan kehedak Allah SWT, tetapi tenang ketika mendapatkan cobaan dan menampakkan sikap cukup walaupun berada dalam kefakiran ekonomi (Nata, 2012: 200). Bersikap sabar sangat dianjurkan di dalam al-Qur'an. Allah berfirman: "Maka bersabarlah kamu seperti orang-orang yang mempunyai keteguhan hati dari rasul-rasul telah bersabar dan janganlah kamu meminta disegerakan (adzab) bagi mereka. Pada hari mereka melihat adzab yang diancamkan kepada mereka (merasa) seolah-olah tidak tinggal (di dunia) melainkan sesaat pada siang hari. (Inilab) suatu pelajaran yang cukup, maka tidak dibinasakan melainkan kaum yang fasik." (Q.S. al-Ahqaf [46]: 35). Dalam konteks pendidikan, bersabar sangat penting. Para siswa, orang tua, kepala sekolah maupun pejabat setempat yang tidak bisa menerima anak (didik) nya tidak lulus Ujian Nasional adalah cermin dari orang yang tidak mau dan tidak kuat bersabar. Akhirnya segala daya dan upaya dikerahkan agar semua siswa/anak didik di sekolah/di wilayah kerja lulus semua meskipun harus menempuh jalan yang curang, tidak jujur dan manipulatif.

Berdasarkan uraian di atas, dalam konteks pendidikan, tasawuf psikoterapi mencoba menerobos hati nurani atau kalbu guru dan murid melalui celah sempit yang masih memungkinkan menanamkan nilai-nilai Ilahiyah sehingga terbukalah harapan untuk memperbaiki generasi penerus bangsa di masa yang akan datang. Indikasi pelaksanaan tasawuf psikoterapi dalam pendidikan Islam tergambarkan dalam wajah murid dan guru yang berseri-seri dalam menerima, mentransfer maupun mengembangkan ilmu. Wajah murung para pendidik dan wajah kaku para murid dalam menerima ilmu menjadi pudar. Setiap proses pembelajaran baik dengan metode ceramah/lisan, demonstrasi, maupun menulis senantiasa disertai senyum ceria namun tetap bersemangat dalam mempersiapkan diri menghadapi setiap persoalan kehidupan di masa yang akan datang. Oleh karena itu, hendaknya guru dalam mengajar, murid dalam belajar dan orang tua dalam 
membiayai anaknya semuanya dimulai dengan ikhlas. Semua elemen yang berhubungan dengan mendidik sama-sama bekerja atas nama Allah bukan demi meningkatkan kesejahteraan, mendambakan pekerjaan dan jaminan kehidupan berlimpah materi. Setiap keberhasilan baik dari murid, guru maupun orang tua selayaknya disyukuri dan setiap kegagalan sepatutnya diterima dengan tawakal. Ada nilai Ilahiyah yang diperjuangkan setiap guru untuk dididikan pada murid demi meningkatkan harkat dan martabat kemanusiaan. Guru memulai pengajarannya dengan santun, jauhkan dari kata-kata jorok sesuai dengan tahap dan perkembangan peserta didik. Bisa saja guru memanggil murid dengan sebutan; eneng, encep, aden atau sejenisnya yang membuat murid merasa nyaman. Halusinasi ambisi orang tua yang mengharapkan bahwa dengan pendidikan kelak anaknya akan bekerja di 'tempat yang basah' dicoba diluruskan dengan cita-cita memperbaiki kualitas hidup, menggugah semangat untuk peduli kepada sesama dengan ilmunya dan membersihkan jiwa yang dikotori oleh harta benda, kesenangan serta kedudukan. Upaya pendidikan pada dasarnya adalah upaya pembimbingan kepada murid dengan cara membangkitkan motivasi hidup murid secara objektif berdasarkan potensi peserta didik. Ide guru tidak perlu terlalu muluk-muluk. Keakuan (anâniyah) guru tidak perlu dipertontonkan kepada murid. Sosok Muhammad dan para sahabat dapat menjadi model yang sesungguhnya bagi murid (Tadjudin, 2007: 620-624).

Dalam penyelenggaraan pendidikan Islam yang berbasis tasawuf psikoterapi mengenyam pendidikan, pengajaran dan memperoleh serta mengembangkan ilmu pengetahuan adalah sebuah kenikmatan yang dikaruniakan Allah kepada manusia. Kenikmatan tersebut tergambarkan dalam tindakan menyebarluaskan ilmu (Q.S. Al-Baqarah [2]: 31), mengajari orang-orang yang tidak tahu menjadi tahu (Q.S. Al-Ankabut [29]: 43) dan (Q.S. At-taubah [9]: 122), menunjukkan jalan yang lurus (Q.S. Al-Fatihah [1]: 6) dan memberi peringatan akan perbuatan-perbuatan yang dapat merugikan umat manusia itu sendiri (Q.S. An-Nisa [4]: 134).

\section{SIMPULAN}

Tasawuf psikoterapi adalah upaya membentuk, memperbaiki dan menyembuhkan jiwa manusia menjadi sehat yang didasarkan pada hubungan yang sehat antara diri dengan Tuhan dan sesamanya. Tanda-tandanya adalah ia tidak pernah menggantungkan diri kepada makhluk lain apalagi benda-benda bukan hanya yang dianggap sebagai pusaka tetapi juga yang berupa kemewahan, kekayaan dan kesenangan yang fana, rusak, lapuk dan sementara. Satu-satunya tempat bergantung adalah Allah SW'T dan martabat hidupnya dipergunakan untuk sebesar mungkin bermanfaat bagi sesamanya. Dengan demikian jiwa yang sehat adalah jiwa yang berserah diri dan ikhlas kepada Allah. Dengan berserah diri, tawakal, sabar, berpola hidup sederhana (zubud dan wara') serta senantiasa bersyukur atas semua nikmat yang diberikan-Nya terdapat keseimbangan di antara seluruh potensi kejiwaan manusia (akal, kalbu, fuad, nafs) sehingga 
keutuhan jiwa akan selalu terjaga dan tetap sehat. Pola tasawuf psikoterapi dapat diterapkan dalam pendidikan khususnya pendidikan Islam baik secara substantif, metodis maupun didaktis. Secara substantif pendidikan Islam bertujuan mengajarkan, memperbaiki, membentuk dan menyembuhkan akhlak yang madrmûmah menjadi akblâq karimah. Inti pendidikan adalah penanaman akhlak bahkan inti agama pun adalah akhlak. Secara metodis, tasawuf psikoterapi mengindikasikan bahwa seyogyanya pendidikan bukan hanya sebagai lembaga yang semata-mata mentransfer ilmu kepada murid-muridnya tetapi lebih dari itu ia merupakan lembaga penuntun dan penyembuh bagi orang-orang yang menderita penyakit kejiwaan sebagai akibat dari pengaruh ketidakjelasan dan keberagaman gejala sosial dan kebudayaan yang sudah mendarah daging pada murid. Misalnya, sudah menjadi budaya bahwa pendidikan dipahami orang tua sebagai jalan untuk meningkatkan tarap hidup keluarga di masa datang. Mestinya secara sufistik tidak demikian, pendidikan adalah lembaga untuk meningkatkan kualitas harkat dan martabat kemanusiaan muridnya untuk meraih kualitas hidup yang lebih baik di masa depan. Secara didaktis, guru dan murid selayaknya seperti hubungan mursyid dengan muridnya. Guru yang profesional dalam pengertian sufistik adalah guru yang telah menempati maqâmat tertentu seperti zubud, wara', at-taubah, dan sabar sehingga ia memiliki kematangan dan santun dalam menghadapi muridnya. Murid pun berada pada posisi manusia seutuhnya bukan dipandang sebagai objek tetapi mitra dalam melatih kedirian guru.

\section{DAFTAR PUSTAKA}

Agustian, Ginanjar, Ary. 2004. Rahasia Sukses Membangkitkan ESQ Power; sebuah Inner Journey Melalui Ibsan. Jakarta: Arga.

Ahmed, Akbar S. 1992. Post Modernism and Islam. Predicament and Promise. London: Routledge.

Al-Abrasyi, Athiyah, Mohammad. 1974. Dasar-Dasar Pokok Pendidikan Islam. terj. H. Bustomi A. Ghani dan Djohar Bahry LIS. Jakarta: Bulan Bintang.

Al-Attas, Naquib, Muhammad, Syed. 1984. Konsep Pendidikan Islam. Bandung: Mizan.

Al-Ghasani, Mahdi. 1993. Filsafat Sains Menurut al-Qur'an. Bandung: Mizan

Al-Ghazali, Imam. 1994. Tabdrib al-Akblaq wa Mu'allajat Amradh al-Qulub. terj. Muhammad Al-Baqir). Bandung: Mizan.

Badri, Malik, B. 1979. The Dilemma Moslem Psychologist. terj. Siti Zainab. Jakarta: Pustaka Firdaus.

Bergin, Allen A. "Psikoterapi dan Nilai-nilai Religius", dalam Jurnal Ilmu dan Kebudayaan Ulumul Qur'an. 1994. No. 4 Vol. V.

Darajat, Zakiah. 1988. Kebahagiaan, Jakarta: Ruhama.

Darajat, Zakiah. 1989. Puasa Meningkatkan Mental, Jakarta: Ruhama.

Davidoff, Linda L. 1988. An Introduction to Psychology. (Terj. Mari Jumiati), Jakarta: Erlangga. 
Effendi, Djohan, "Tasawuf Al-Qur'an Tentang Perkembangan Jiwa Manusia" dalam Jurnal Ilmu dan Kebudayaan, Ulumul Qur'an. 1991. No.8.

Frankl, Viktor E. 1970. The Will to Meaning: Foundations Aplications of Logoterapy. New American Library.

Harian Sijori Mandiri. 2007. edisi Kamis, 21 Juni.

Hawwa, Sayyid. 1998. Tarbiyah al-Ruhaniyah. terj. Kahirul Rafie. Bandung: Mizan.

Jalal, Fatah, Abdul. 1990. Azas-Azas Pendidikan Islam. terj. Herry Noer Ali. Bandung: Diponegoro.

Jaya, Yahya. 1992. Peranan Taubat dan Maaf Dalam Kesehatan Mental. Jakarta: Ruhama.

Jaya, Yahya. 1992. Spiritualisasi Islam dalam Menumbubkembangkan Kepribadian dan Kesehatan Mental. Jakarta: Ruhama.

Ma'luf, Lois. 1986. Munjid fi al-Lughah wal A'lam. Beirut: Maktabah al-Syarkiyyah:

Madjid, Nurcholish. 1992. Pintu-Pintu Menuju Tuhan. Jakarta: Paramadina.

Malony, H. N. 1997. Current Perspektives in the Psychology of Religion. Grand Rapids: Mich Ferdmans.

Marimba, Ahmad, D. 1980. Pengantar Filsafat Pendidikan Islam. Bandung: AlMa'arif.

Miskawaih, Ibn. 1961. Tahdzî̉ al- Akhlâq. Beirut: Manshurat Dar al-Maktabah alHayat.

Najati, Utsman, Muhammad. 1993. al-Hadits an-Nabawi wa ilmu al-An-nafs. Beirut: Dar al-Syuruq.

Najati, Utsman, Muhammad. 2001. Al-Qur'an wa 'Ilm al-Nafs. al-Kaherah: Dar alSyuruq.

Nasution, Harun. 1997. Islam Rasional, Bandung: Mizan.

Nata, Abuddin. 2012. Akhlak Tasawuf. Jakarta: Rajawali Press.

Nurbakh, Javad. "Tasawuf dan Psikoanalisa: Konsep Iradah dan Transferensi dalam Psikologi Sufi", dalam Jurnal Ilmu dan Kebudayaan. 1991. Ulumul Qur'an, No. 8.

Pasiak, Taufik. 2004. Revolusi IQ EQ, SQ, antara Neorosains dan al-Qur'an. Bandung: Mizan.

Polanyi, M. 1962. Personal Knowledge: Towards a Postcritical Philosophy. Chicago: University of Chicago Press.

Rahman, Munawwar, Budhi. 1995. Kontekstualisasi Doketrin Islam dalam Sejarah. Jakarta: Paramadina.

Rahmat, Jalaluddin. 1991. Islam Aktual. Bandung: Mizan.

Rahmat, Jalaluddin. 1999. Renungan-Renungan Sufistik. Bandung: Mizan.

Syariati, Ali. 1995. The Englightened Thinkers and Islamic Renaisance. terj. Rahmani Astuti. Bandung: Mizan.

Wilcox, Linn. 2003. Sufism and Psychology. terj. IG. Harimurti Bagoesoka. Jakarta: Serambi Ilmu Semesta.

Wundt, Wilhelm. 1973. An Introduction Psychology. New York: Arno Press.

Zahri, Mustafa. 1995. Kunci Memahami Tasawuf. Cet I. Surabaya: Bina Ilmu. 